\title{
Socio-Economic Implications of Covid19 Pandemic to Women Entrepreneurs: A Case of the Informal Sector in Zimbabwe
}

\author{
Rahabhi Mashapure \\ Dept. of Entrepreneurship, Chinhoyi University of Technology \\ P BAG 7728, Chinhoyi, Zimbabwe
}

Tel: 0267-21222003-5 E-mail: rmashapure@cut.ac.zw

\author{
Purity Hamunakwadi \\ Department of Sociology, North-West University \\ P BAG X6001, Potchefstroom, South Africa
}

Tel: 0182991779 E-mail: phamuna@gmail.com

Desderio Chavunduka

Graduate Business School, Chinhoyi University of Technology

P BAG 7728, Chinhoyi, Zimbabwe

Tel: 0267-21222003-5 E-mail: dchavunduka@gmail.com

\author{
Lovemore Chikazhe (Corresponding author) \\ Retail Management Department, Chinhoyi University of Technology \\ P BAG 7728, Chinhoyi, Zimbabwe
}

Tel: 0267-21222003-5 E-mail: chikazhelb@gmail.com

Received: November 4, 2020 Accepted: December 1, 2020 Published: December 8, 2020 doi:10.5296/bms.v12i1.17911ＵRL: https://doi.org/10.5296/bms. v12i1.17911 


\section{Abstract}

The purpose of the study was to establish the effect of Covid-19 pandemic to women entrepreneurs in the informal sector of Zimbabwe. A qualitative study was conducted in Mashonaland West province in Zimbabwe. Data was collected through telephone interviews from 16 informal business women entrepreneurs in the retail sector. The participants were involved businesses that include; vegetable vending, operating clothing flea market and cross border trading. The study established that business for women entrepreneurs in the informal sector were affected by inter-province travelling regulations. It was also established that women were most affected as they are responsible for making sure that children are fed on daily basis. To make matters worse, some were widows and others were looking after many orphans. This to a larger extent encouraged cases of strained relationship in the home because of inadequate resources especially food. Cases were also reported of gender-based violence because all members of the family were now spending most of their time together with little resources to use in looking after the family. Thus, health problems such as high blood pressure and were also witnessed. The study recommended the government to provide protective equipment and sanitizers to women entrepreneurs and informal traders so that they can safely continue to produce, distribute and sell their merchandise. The government should assist with transport for smallholder farmers to ferry their produce to markets safely. Also, the government was recommended to communicate with market leaders about how to best handle a lockdown and reopening.

Keywords: Socio-Economic Implications, Covid-19 Pandemic, Women Entrepreneurs, Informal Sector, Zimbabwe

\section{Introduction}

The advent of the Coronavirus disease (Covid-19) in December 2019 was sudden and devastating in every respect. The pandemic was declared a global pandemic by the World Health Organization (WHO) on 11 March 2020 since it has impacted the entire world population and their economies (African Union, 2020). Having its origins, in Wahun China, the disease has spread and affected virtually all parts of the world (African Union, 2020). The pandemic caused unprecedented economic challenges in people's livelihoods. Throughout the globe, but particularly in developing world, the Covid-19 pandemic threatens to cause massive disruptions in the livelihoods of the people. In the recent months the Zimbabwe's Covid-19 statistics rose triggering the government to tighten travel movements as well as business operations. The coronavirus pandemic further pushed the plight of the jobless to extreme poverty and helplessness. With an unemployment rate of over $80 \%$, many Zimbabweans depend on informal business for survival. These informal businesses were the worst affected by the restrictions because of the pandemic. The negative impacts are more pronounced in urban set-ups where there is hardly any alternative means of survival for them. This qualitative study focuses on how the livelihoods of women entrepreneurs in the informal sector of Zimbabwe have been affected. 


\section{Literature Review}

Information about the coronavirus pandemic is available everywhere. What may not be easily available is literature on its effects on the livelihoods of people, especially women. The Organization for Economic Cooperation and Development (OECD) notes that the coronavirus (COVID-19) outbreak has already brought considerable human suffering and major economic disruption (OECD, 2020). According to Gennaro et al. (2020) the outbreak is a clear and extraordinary disaster particularly in countries like China, USA, Italy and Iran. These countries are plagued most in every aspect, especially health, social and economic areas. Likewise, Ozili (2020) observes that the COVID-19 pandemic has affected the global economy with spillovers to African countries. As the effects of the pandemic are creeping into Africa, Zimbabwe has not been spared. Although, many African countries have taken bold quarantine and lockdown measures to control the spread of COVID-19, there already has been much collapse of health systems and a painful economic crisis or recession.

Asudani et al. (2020) argue that historically there have been various pandemics that have affected people's lives like Influenza, Black Death, Ebola, severe acute respiratory syndrome (SARS) and other related crises that have prompted huge negative effects on economies, health and national securities in the world. For instance, in Peru when there was a cholera outbreak in 1991, they lost US\$12.9 million (Asudani, Dudhani \& Lachhwani 2020). The Organization for Economic Cooperation and Development (OECD) confirms that in comparison to the similar incidents that occurred in the past, like SARS outbreak in 2003, the global economy is interconnected. (OECD, 2020:3). The outbreak of SARS in 2003 impacted the economy negatively particularly in tourism, consumption and travel-related services but the corona virus has superseded this record. This means that the pandemic has heavily affected the economy and many of people suffer as job losses are inevitable. The lessons are clear from the past. Ebola impacted caused a decline in exports in various countries: $38 \%$ in Liberia, $20 \%$ in Sierra Leone and $10 \%$ in Guinea (Asudani, Dudhani \& Lachhwani, and 2020:157). The Spanish Flu in Sweden had negative implications on the labour supply which affected capital returns yet wages were increasing resulting in expensive human capital and instead of using the resources in production of goods they were channeled to support human capital resulting in reducing the growth rate of the economy (Karlsson Nilsson \& Pichleret, 2012).

The effects of the Covid-19 are poised to be worse in African economies; Zimbabwe in particular, because the people there rely mostly from informal trading. There is a grave situation at hand. Many livelihoods of the citizens are in danger. It can be estimated that in 2020, due to the slowdown in economic activities and ongoing of lockdown, there will be severe downfall of trade globally which is affecting all sectors of the economy. The World Trade organization (WTO) estimates that the global trade will fall by up to $32 \%$ this 2020 due to the Covid-19 pandemic (Asudani, Dudhani \& Lachhwani, 2020:158). In this regard, Covid-19 is affecting the global economy on various platforms including, supply chain, production, disruption of the market and the financial sector. It is crucial to note that more 
critical features of Covid-19 may still be yet to be discovered and understood hence it is essential to track latest information and take necessary steps about it.

Covid-19 pandemic is likely to cause more harm than past pandemics to those world economies that rely on the informal sector. Therefore, as the Covid-19 crisis continues to unfold across the world, informal workers remain exceptionally vulnerable to the economic and labour market shocks (Shaikh, 2020). Zimbabwe's economy is highly informal. Many of these workers are likely to lose their jobs and face extreme poverty and food insecurity as the disease intensifies across large informal economies, such as those in Zimbabwe. The risk of civil unrest and social tension also grows making the plight of informal workers a major political worry.

The inadequate regulatory, policy and legislative structure to reach informal workers in the region makes it more challenging for governments to provide relief and take measures to restore basic livelihoods for informal workers at this time. Statistics of informal sector remains poorly understood in Zimbabwe but using statistics from other countries, the informal sector is suffering and demands urgency in action to be regulated as it constitutes more than half of the employed population. For example, assessments of the informal employment held in South Asia in 2018, estimated that over two billion (61.2\%) of the world's employed population is informal. For India almost $90 \%$ of the 500 million workers are part of the informal sector, contributing to at least half of the national gross domestic product (GDP). Yet India is the world's third largest economy. Bangladesh has more than $85 \%$ (over 25 million) of the labour force in informal, amounting for almost 50\% of the GDP. In Pakistan, up to $72 \%$ of the jobs outside agriculture are in the informal sector, contributing a third of the GDP.

Ozili (2020) is of the view that social distancing has led to shutdown of corporate offices, businesses, events and financial markets. Also, the increase in number of lockdown days due to Covid-19 is continuously affecting the level of economic activities like monetary policy decisions and international travel restrictions. However, Rehman, Khan, Zainab, Ahmed, Ishaq and Ullah (2020) note that people are unaware of the health benefits of social distancing, hence they do not seem to care much about it. Social distancing helps health wise but economically it has drastic effects on people's lives since the majority may not be able to buy food since they rely mostly on precarious work like informal trading. In the same vein, the African Union (2020:5) argues that "global growth could fall by $0.5 \%$ for the year 2020." This fall of the global growth has negative implications on the economies world-wide because it hampers international trade. In this regard and due to the fact that Africa is open to international trade and migration, it may not be safe to continue trading in the face of the harmful effects of Covid-19. The African Union (2020:5) specifies that exogenous and endogenous effects may hamper the country economically as follows: "The exogenous effects come from direct trade links between affected partner continents such as Asia, Europe and the United States; tourism; the decline in remittances from African Diaspora; Foreign Direct Investment and Official Development Assistance; illicit financing flows and domestic 
financial market tightening, etc. The endogenous effects occur as a result of the rapid spread of the virus in many African countries. On one hand, they are linked to morbidity and mortality. On the other hand, they lead to a disruption of economic activities. This may cause a decrease in domestic demand in tax revenue due to the loss of oil and commodity prices coupled with an increase in public expenditure to safeguard human health and support economic activities." This shows that Covid-19 has negative impacts in various countries and African nations and Zimbabwe is not exempted.

African nations, Zimbabwe in particular, depend much on remittances from South Africa. In this regard, as stipulated by Dodson, Simelane, Tevera, Green, Chikanda and de Vletter (2008) remittances from migrants are a crucial source of income in developing countries which gives it international attention. Importantly, there is need to understand that the patterns and processes of remittance on recipient households contribute to socio-economic development in the country where the migrants originate. In the wake of this Covid-19 pandemic, there will be limited remittances due to closure of borders. Covid-19 therefore has brought in negative effects to the lives of people and their economies.

Informal trading is defined as the economic activity undertaken by entrepreneurs who sell legal goods and services within a space deemed to be public property, within the informal sector (Cross, 1997; Ukukhula, 2004). Informal used to refer to that segment of labour market in the developing countries that has absorbed significant numbers of jobseekers, mostly in self-employment, and to workers in very small production units (ILO, 2000). Argueably Zimbabwe can be now be said to be a "nation of traders" as observed by Kumbirai Katsande, President of the Confederation of Zimbabwe Industries (Integrated Regional Information Networks: IRIN, 2013). Report by Doris Kumbawa, Financial Gazette, Zimbabwe, HARARE, 12 June (2002) views informal trading as the major employer of Zimbabwe.

The informal economy has been known to be an effective tool for the alleviation of poverty and creation of a support base for sustainable livelihoods (Henning and Akoob, 2017). Indeed, some of the most significant economic and social developments in the world point to the emergence of a growing community of women entrepreneurs who for a greater part operate on an informal basis. In developing economies, women have been heading households in various ways. For instance, Henning and Akoob (2017) argue that "in some parts of Kenya and Tanzania, over $50 \%$ of households are headed by women because of the migration of men to urban industrial sectors." In this respect, women are a powerful force in their communities especially the developing nations.

The economic operations of these women remain informal; only disappearing upon achieving sufficient economic growth (Chen, 2012). It is still a long way to go for most African countries to achieve the formalization because their economies are still developing. In the informal sector, the women are involved in various entrepreneurial activities which include street vending, food markets, taxi drivers, home based care workers, rubbish collection and cross boarder trading. It should be borne in mind that because the businesses are informal, they are unregistered, difficult to regulate and taxed and are usually run from street 
pavements or homes (Horn, 2011). Wilkinson (2013:14) notes that "these units typically operate at a low level of organization with little or no division between labour and capital factors or production and on a small scale. They have low bargaining power and fierce cost cutting competition render them unable to operate like formal sector entities." This shows that the informal sector is disadvantaged in a number of ways because they face stiff competition from various entities yet they rely mostly on a conducive environment but that is not the case due to Covid-19. The following figure shows the percentages of women in informal employment across the world.

Table 1. Statistics of women in informal employment

\begin{tabular}{|c|c|c|}
\hline \multicolumn{3}{|c|}{ Women in informal employment as a percentage of total employment } \\
\hline South Asia & $95 \%$ & $\begin{array}{l}\text { Informal workers can include: } \\
\text { Street vendors }\end{array}$ \\
\hline Sub Saharan Africa & $89 \%$ & $\begin{array}{l}\text { Subsistence farmers } \\
\text { Seasonal workers }\end{array}$ \\
\hline Latin America and the Caribbean & $59 \%$ & $\begin{array}{l}\text { Domestic workers } \\
\text { Industrial outworkers }\end{array}$ \\
\hline
\end{tabular}

Source: Adapted from (UN-Habitat, 2020)

As depicted in figure 1 above, globally the least percentage engagement of women in informal employment in 59\% Latin America. Because the main source of income of the women is through informal employment, the advent and prevalence of Covid-19 inevitably puts their socio-economic wellbeing is at stake. In fact, with the lockdowns, it means that the informal sector loses their source of income (UN Habitat, 2020).

The International Labour Organization observes that when people go into informal employment, it is out of the need to survive; it is because they need to feed their families and usually they do not have other means of obtaining an income neither do they have savings (ILO, 2020). The ongoing lockdowns mean they are not working and so not earning any income. While the threat of contracting the virus is real for over 2 billion workers earning their livelihoods in the informal economy, livelihoods are also at stake. Informal employment represents $90 \%$ of total employment in low-income countries, $67 \%$ in middle-income countries and $18 \%$ in high-income countries" (ILO, 2020:1). This shows that African countries are more at risk since they rely mostly on the informal economy and in this regard, Zimbabwe is not exceptional. Women are often more vulnerable than their male counterparts because they are exposed to informality in low-and -lower-middle income countries. It also is important to note that informal enterprises are small, employing few low-skilled workers including women or other family workers who work in precarious conditions, paid low wages and mostly without social protection, security and healthy measures at the workplace. Their productivity, rates of savings and investment is very low resulting in their vulnerability to economic shocks and as is the case in Zimbabwe, without any Covid-19 crisis-related 
short-term financial assistance programmes for businesses. Mazwi and Mudimu (2020) view Zimbabwe as one of the countries whose household-level food system is sustained by the activities of subsistence smallholders (Mhlanga \& Ndlovhu, 2020).

Generally, all over the world, women are more likely to be single parents, meaning those women provide financial support to more dependents on that income and their households often dependent solely on a single source of income and (Cohen, 2010). As a result, intensified pressure is likely to impact negatively the women's mental and physical health (Cohen \& Venter, 2020; Geurts, Taris, Kompier, Dikkers, Van Hooff, \& Kinnunen, 2005).

Arguments might arise on the philanthropic activities being done by Non-Governmental Organizations but the question still remains on how much the people are receiving and how sustainable the activities can be. For instance, those in urban areas need to pay for rentals and, for those with school children, they want to help their children access online teaching services. But if their businesses remain unopened, the concern is how they are going to obtain all such services.

It can be said that the informal sector has become the unofficial backbone of the economy and the engine of growth and development in creating employment for the majority and the marginalized. This way the informal sector enhances the poverty alleviation and development strategy (Mbiriri, 2010). In many developing nations, self-employment and small enterprises in the informal sector has absorbed some of those workers who had lost their jobs in the formal economy since the late 1980s (Chidoko, Makuyana, Matungamire, \& Bemani, 2011).

There is therefore need to find have deeper understanding of the impact of the Covid-19 at the local level with a view to finding ways of preserving the livelihoods of people in the informal sector (Renzaho, 2020). It is against this background that this study focuses on the socio-economic implications of Covid-19 to women entrepreneurs in informal traders, Zimbabwe.

\section{Methodology}

The study used the qualitative research approach and due to Covid-19 related restrictions on contacts and travelling from one place to another, telephone interviews were used to collect responses for the study. The participants, 16 informal women entrepreneurs in the retail sector in Makonde district of Mashonaland West Province of Zimbabwe, were the key sources of data. Initially only a few women were identified and using the snowball effect these helped the researchers to identify more of women that had been involved in the business. The saturation point was 16; when no new responses were forthcoming. The interviews sought mainly to establish the nature of livelihoods women entrepreneurs were into and the challenges faced since the outbreak of the pandemic; including suggested needs from local authority or other sources to sustain their livelihoods. The women involved in the study were of various ages range as indicated in Table 2. The mainstay of their business was informal trading and they had been in the business for at least six months. 


\section{Results}

Most of the participants were identified to be within 18 to 60 age range. See demographic Table 2 below.

Table 2. Age of participants

\begin{tabular}{|l|l|}
\hline \multicolumn{2}{|c|}{ Age of participants } \\
\hline Below 18 & $11 \%$ \\
\hline 18 to 30 & $40 \%$ \\
\hline $31-60$ & $44 \%$ \\
\hline Above 60 & $5 \%$ \\
\hline
\end{tabular}

This data indicates that the active age group is from 18 to 60 years made up of $84 \%$ of total participants. This age group is mostly the married women, the divorced and the widows. The study results indicate that marriage status motivates them to engage into entrepreneurship as a survival strategy. Hence the percentage decreases as age grows high due to the healthy problems increase of revenue streams. As some of them will be receiving financial support from their children and the government through social schemes which caters for the elderly. Also, family responsibilities oftentimes decrease with age as most of their children will be married and looking after themselves. Those below 30 are the ones in most cases being forced by their situations to engage into entrepreneurship. That is assisting parents with either paying their own school fees or providing for the family. Some of them are orphans and they have nowhere and no one to look up to. Therefore, if the Covid-19 regulations are not relaxed, there is high risk of engaging in illegal unlawful activities such as prostitution so that they earn a living. Thereby creating a generation of poverty as they will be exposed to diseases and unwanted pregnancy.

\subsection{Levels of Education}

In terms of education, the majority of respondents $(91 \%)$ had attained at least ordinary level certificate, with some women in possession of university degrees being part of the sample. See Table 3 below.

Table 3. Respondents' education

\begin{tabular}{|l|l|}
\hline Level of education & Participants \\
\hline Ordinary level & $91 \%$ \\
\hline Diploma Level & $2 \%$ \\
\hline University Level & $7 \%$ \\
\hline
\end{tabular}

The graph shows that informal trading is not restricted to the uneducated, in fact, given the unemployment rate in Zimbabwe; the number of degreed women in informal business is expected to rise steadily in the near future. 


\subsection{Nature of Livelihoods Engaged by Women Entrepreneurs}

The livelihoods of women entrepreneurs can be categorized into 3:

a) Vegetable vending: these have a number of products whose variety depends on the season but they mainly deal with green vegetables, potatoes and a variety of legumes like beans and ground nuts. Women often travel to purchase these vegetables from the market. Some of them used to buy the vegetables from local farmers. The advent Covid-19 prevented all this.

b) Clothing flea market operating: Mainly this focused on used clothes, shoes and related accessories. Again, business in this area came to a standstill as the customers were not available due to restricted movement.

c) Cross border trade: Borders were al closed. Most of the participants (84\%) were cross border trading who were also into flea market operating. Only $40 \%$ highlighted that they are into flea market but they purchased products from others who are into cross border trade.

Table below shows income generated by women entrepreneurs before the outbreak of the pandemic.

Table 4. Profits generated by respondents per day

\begin{tabular}{|l|l|l|l|}
\hline Livelihoods & Products & Quantity & $\begin{array}{l}\text { Income per day } \\
\text { US\$ }\end{array}$ \\
\hline \multirow{3}{*}{ Vegetable vending } & Green vegetables & 50 bundles & 50.00 \\
\cline { 2 - 4 } & Potatoes & 10 to 15 pockets & 80.00 to 150.00 \\
\cline { 2 - 4 } & Variety of legumes & $10 \mathrm{~kg}$ & 60.00 \\
\hline \multirow{2}{*}{ Clothing flea market } & Clothes & 20 & 300.00 \\
\cline { 2 - 4 } & Shoes & 20 & 200.00 \\
\hline Cross border trade & Groceries and Others & & 50.00 \\
\hline Hairdressing & & 6 customers & 60.00 \\
\hline
\end{tabular}

However, after the enactment of the Covid-19 regulations by the government, women entrepreneur's business became constrained.

\subsection{Challenges Faced by Women Entrepreneurs Since the Outbreak of the Pandemic}

According to the Covid-19 regulations for Zimbabwe inter-province travelling was not allowed. Thus, women entrepreneurs with business based on buying and selling was at stake. Also, those who were into flea market trading were facing challenges because of strict policies put in place by the government. The restrictions were restricting them to move from one place to another. For anyone to move into another district or province, one had to get authority from the Police. Even those women entrepreneurs who practiced backyard gardening were affected because they could not move around selling their merchandise. At the height of the lockdown, much of the perishable stocks became stale and this was a 
complete loss. Those with unperishable merchandise had their capital tied on the stocks.

Lockdown period disturbed informal businesses yet millions of Zimbabweans make a living out vending. The lockdown remained in place for long while government was consulting health specialists on how to reopen business and operate under such conditions (Omondi, 2020). Women were most affected as they are responsible for making sure that children are fed on daily basis. To make matters worse, some were widows and others were looking after many orphans. This to a larger extent encouraged cases of strained relationship in the home because of inadequate resources especially food. Cases were also reported of gender-based violence because all members of the family were now spending most of their time together with little resources to use in looking after the family. Thus, health problems such as high blood pressure and were also witnessed.

The most painful part of the affected population with these problems is that they had in most cases nowhere to rely on. There are a few women that remained unaffected. The few women entrepreneurs who remained operating their businesses are seem to doing so through corruption and connections with the law enforcers. Thus, the need for urgent loosening of the pandemic regulations.

It was observed that during the interviews that these women entrepreneurs operated in a network of others. So, the Covid-19 restrictions did not only affect women entrepreneurs or business owners but their suppliers and customers were also victims.

\section{Recommendations}

Making recommendations for the alleviation of the plight of women affected in this pandemic was not easy. Even the respondents themselves were hard-pressed to define a possible way forward in terms of how to rescue the situation. This is understandable given the fact that the pandemic had suddenly appeared and no one was responsible for the fate. This was more so because it was not clear the progression of the disease. However, the study notes the merger comments and suggestions made by the respondents and has used these to chat a way forward. The participants admitted that they were aware of the grave effects of the pandemic especially that this had affected their livelihoods. The following are suggestions and recommendation for the amelioration of the covid-19 pandemic.

- Perhaps it may be prudent that the government provides personal protective equipment to women entrepreneurs and informal traders so that they can safely continue to make a living in their trade. There has however to be vigilance to ensure compliance to safety regulations so that the disease can be contained, In the same vein the government should assist with transport for smallholder farmers to ferry their produce to markets safely. Public transport is hardly available during the lockdown. In each district, farmers can organize to ferry their products to a central place where the government provides transport to different designated markets within a reasonable distance. Transport logistics and delivery should ensure social distancing. 
- It is clear from the respondents that there is need for local government to adjust the lockdown and reopening of informal business. They suggest the temporary relaxing of bylaws that prevent citizens from selling outside their homes, which would still provide some income and help discourage travel to markets. This is supported by Resnick (2020) who suggests other feasible options include opening markets every other day and sanitizing on the off days and allowing for trading around the clock reducing consumer congestion. Local authorities could also set up new markets to prevent women entrepreneurs overcrowding and ensure social distancing in traditional marketplaces. Community halls and sports fields that are near residential areas can be used as food markets. Those urban poor who live hand to mouth need to gain access to food in nearby spaces.

- The government needs to speedily compensate farmers and informal traders whose produce was confiscated and destroyed by the state during the lockdown. This would enable the farmers to rebuild their livelihoods, feed families and other citizens. On the other hand, the municipalities should waiver tax for the registered informal food traders during the lockdown period.

- The Government of Zimbabwe, 2020 Statutory Instrument 99 of 2020 set out the re-opening procedure for businesses (Mutambanengwe, 2020). A key point in the re-opening procedure includes proving that the business is formal, as indicated by any one of the following

○ Having a shop license or other operating license; or

○ Having a formal lease; or

○ Being registered with the Zimbabwe Revenue Authority (ZIMRA); or

○ Being part of a recognized National Employment Council. (Mutambanengwe, 2020)

This stipulation excludes the majority of traders who have remained informal. Respondents appreciate the move by the government of reopening of SMEs but the current statutory instrument is not supporting informal trading yet the most affected population are informal traders. Considering the small returns of their business they cannot meet the demands and fulfil the process needed for them to be regarded as formal traders as stated by the current statutory instrument announced on the $4^{\text {th }}$ of May 2020.

ZW \$500 million COVID funding targeting SMEs was also announced by the government on 4 May 2020. SMEA (2020) highlights that although detailed guidelines have not been given on how the funds will be disbursed, the President indicated that it will be through the formal financial sector so the informal sector, which contains the majority, will not benefit (Price, 2020). There should be constituted a mechanism to make benefits accrue to the informal sector e.g. by relaxing the standard loan application requirements to access the funding. An example could be removing the requirement for collateral 


\section{Conclusions}

The informal sector is likely to realize worse effects of the pandemic and re-thinking existing business models to adjust to the changes is urgent. From cross-border traders to mere street vendors, the story of loss of income is now common. As the national government, local authorities and affected individual should continue to devise a strategic roadmap to navigate through uncertainty, there are common lessons being learned.

\section{References}

African Union. (2020). Impact of the coronavirus (Covid-19) on the African economy. https://au.int/sites/default/files/documents/38326-doc-covid19_impact_on_african_economy. pdf. Date of access: 2 June 2020.

Asudani, N., Dudhani, J., \& Lachhwani, H. (2020). Corona Virus and India: Economic and Sectorial Implications. International Journal for Research in Engineering Application \& Management (IJREAM), 6(1),156-163. https://doi.org/10.35291/2454-9150.2020.0274

Chen, M. A. (2012). The informal economy: Definitions, theories and policies, Women in Informal Economy Globalising and Organizing: WIEGO Working Paper, 1.

Chidoko, C., Makuyana, G., Matungamire, P., \& Bemani, J. (2011). Impact of the Informal Sector on the Current Zimbabwean Economic Environment. International Journal of Economics and Research, 02(06), 26-28.

Cohen, J. (2010). How the global economic crisis reaches marginalised workers: The case of street traders in Johannesburg, South Africa. Gender and Development, 18(2), 277-289. https://doi.org/10.1080/13552074.2010.491345

Cohen, J., \& Venter, W. D. F. (2020). The integration of occupational- and household-based chronic stress among South African women employed as public hospital nurses. PLoS ONE, 15(5), 1-30. https://doi.org/10.1371/journal.pone.0231693

Cross, J. C. (1997). Entrepreneurship and Exploitation: Measuring Independence and Dependence in the Informal Economy. International Journal of Sociology and Social Planning, 17, Cairo, Egypt. https://doi.org/10.1108/eb013300

Dodson, B., Simelane, H., Tevera, D., Green, T., Chikanda, A., de Vletter, F., \& Crush, J. (2008). Gender, Migration and Remittances in Southern Africa. Southern African Migration Project: Migration Policy Series No. 49. Idasa: Cape Town, Southern African Research Centre. Retrived from https://media.africaportal.org/documents/Migration_Policy_Series_No._49.pdf. Date of access: 28 May 2020.

Doris, K. (12 June 2002). Financial Gazette, Zimbabwe, HARARE. http://www.gdrc.org/informal/6-zimbabwe.html.

Gennaro, F. D., Pizzol, D., Marotta, C., Antunes, M., Racalbuto, V., Veronese, N., \& Smith, L. 
(2020). Coronavirus Diseases (COVID-19) Current Status and Future Perspectives: A Narrative Review. International Journal of Environmental Research and Public Health, 17(2690), 1-11. https://doi.org/10.3390/ijerph17082690

Geurts, S. A. E., Taris, T. W., Kompier, M. A. J., Dikkers, J. S. E., van Hooff, M. L. M., \& Kinnunen, U. M. (2005). Measuring negative and positive work-home interaction: Development and validation of a new questionnaire. Journal of Vocational Behavior, 63, 532-559. https://doi.org/10.1016/S0001-8791(02)00025-8

Henning, S., \& Akoob, K. (2017). Motivational factors affecting informal women entrepreneurs in North-West Province. Southern African Journal of Entrepreneurship and Small Business Management, 9(1), 1-10. https://doi.org/10.4102/sajesbm.v9i1.91

Horn, A. (2011). 'Who's out there? A profile of informal traders in four South African city central business districts'. Town and Regional Planning, 59, 1-6.

International Labour Organistion Newsroom.

(2020). https://www.ilo.org/global/about-the-ilo/newsroom/news/WCMS_744005/lang--en/index.htm IRIN. (2013). Informal employment sustains Zimbabweans, 11 April 2013. Available at https://www.refworld.org/docid/5178f4be4.html [accessed 25 November 2020].

Mazwi, F., \& Mudimu, G. (2020). Why Are Zimbabwe'S Land Reforms Being Reversed? [Online] Economic and Political Weekly. Available at: [Accessed 15 March 2020]. https://thesaharan.com/wp-content/uploads/2020/10/Socio-economic-Implications-of-the-CO VID-19-1-1.pdf

Mbiriri, R. P. (2010). Can Zimbabwe Use Its Informal Economy As a Means for Sustainable Development, 1-85.

Mhlanga, D., \& Ndhlovu, E. (2020) Socio-Economic Implications of the COVID-19 Pandemic for Smallholder Farmer Livelihoods in Zimbabwe. The Saharan Journal, 1(2), $\begin{array}{lllll}\text { National Institute for } & \text { African } & \text { Studies }\end{array}$ https://thesaharan.com/wp-content/uploads/2020/10/Socio-economic-Implications-of-the-CO VID-19-1-1.pdf https://doi.org/10.20944/preprints202004.0219.v1

Mutambanengwe, F. (2020). Procedure for re-opening of business, and access to funding for SMEs. SME Association of Zimbabwe (SMEA). https://www.smeaz.org.zw/component/acymailing/listid-4/mailid-3172-procedure-for-re-open ing-ofbusiness-and-access-to-funding

OECD Interim Economic Assessment Coronavirus: The world economy at risk (2 March 2020). https://www.oecd.org/berlin/publikationen/Interim-Economic-Assessment-2-March-2020.pdf OECD Policy Responses to Coronavirus (COVID-19). The impact of the coronavirus (COVID-19) crisis on development finance. (24 June 2020). 
http://www.oecd.org/coronavirus/policy-responses/the-impact-of-the-coronavirus-covid-19-cr isis-on-development-finance-9de00b3b/

OECD. (2020). The impact of the coronavirus (COVID-19) crisis on development finance. $(24$ June

2020). http://www.oecd.org/coronavirus/policy-responses/the-impact-of-the-coronavirus-covid-19-cr isis-on-development-finance-9de00b3b/

Omondi, J. (May 16, 2020). Zimbabwe to ease COVID-19 restrictions, but lockdown to stay for

now. https://africa.cgtn.com/2020/05/16/zimbabwe-to-ease-Covid-19-restrictions-but-lockdown-tostay-for-now/

Ozili, P. K. (2020). COVID-19 in Africa: socioeconomic impact, policy response and opportunities. International Journal of Sociology and Social Policy, SSRN Electronic Journal, 1-34 . https://doi.org/10.2139/ssrn.3574767

Ozili, P. K. (2020). Covid-19 pandemic and economic crisis: The Nigerian experience and structural causes. https://doi.org/10.2139/ssrn.3567419

Price, R. A. (2020). Impacts of COVID-19 regulatory measures on small-scale and informal trade in Zimbabwe. K4D Helpdesk Report 815-816. Brighton, UK: Institute of Development Studies.

https://opendocs.ids.ac.uk/opendocs/bitstream/handle/20.500.12413/15323/815_816_Covid1

9_and_trade_in_Zimbabwe_final.pdf?sequence $=1 \&$ isAllowed $=y$

Rehman, I., Khan, H., Zainab, W., Ahmed, A., Ishaq, M., \& Ullah, I. (2020). Barriers in Social Distancing during Covid-19 pandemic - Is a message for forced lockdown. $J$ Med Res Innov, 4(2), 1-7. e000222. https://doi.org/10.32892/jmri.222

Renzaho, A. M. N. (2020). Challenges Associated With the Response to the Coronavirus Disease (COVID-19) Pandemic in Africa-An African Diaspora Perspective. Risk Analysis: an Official Publication of the Society for Risk Analysis, 18 Sep 2020. https://europepmc.org/authors/0000-0002-6844-0833

Resnick, D. (2020, 31 March). COVID-19 lockdowns threaten Africa's vital informal urban food trade. IFPRI Blog. [Blog]. Retrieved from https://www.ifpri.org/blog/covid-19-lockdowns-threatenafricas-vital-informal-urban-food-tra de https://doi.org/10.2499/p15738coll2.133762_16

Shaikh, H. (2020). Responding to the impacts of COVID-19 on informal workers in South Asia.

https://www.theigc.org/blog/responding-to-the-impacts-of-covid-19-on-informal-workers-in-s outh-asia/

Ukukhula. (2004). Informal Trading Policy and Management Framework. Adopted by the Mayoral Committee of the City of Cape Town on 18 February 2004. 
UN Habitant Women, Progress of the World's Women (2015-2016). Chapter 2, p. 71. https://www.unwomen.org/en/news/in-focus/csw61/women-in-informal-economy

UN Habitant Women, Progress of the World's Women (2015-2016). Chapter 3, p. 147. https://www.unwomen.org/en/news/in-focus/csw61/women-in-informal-economy

Wilkinson, F. (2013). The dynamics of labour market segmentation. London: Elsevier.

Zamchiya, P., Mavhinga, D., Gwinji, T., Chamunogwa, A., \& Madhuku, C. (2020, 20 April).

Interview guide for women entrepreneurs

\begin{tabular}{|c|c|}
\hline Theme 1 & $\begin{array}{l}\text { What is the type of your business? } \\
\text { 1. For how long have you been operating this type of business? } \\
\text { 2. What triggered you to start this business? } \\
\text { 3. What is your highest qualification? } \\
\text { 4. Do you think being educated has a positive impact in a } \\
\text { business? } \\
\text { 5. Compare your business performance before, during and after } \\
\text { Covid19 lockdown. }\end{array}$ \\
\hline Theme 2 & $\begin{array}{l}\text { 1. What are the challenges being faced in operating your business } \\
\text { during this Covid19 pandemic era? }\end{array}$ \\
\hline Theme 3 & $\begin{array}{l}\text { 1. Is there any help you are in need in case covid19 regulations and } \\
\text { restrictions does not change? } \\
\text { 2. What help are you expecting to the government? Local } \\
\text { authority? Your neighbors.? }\end{array}$ \\
\hline & Any additional information \\
\hline
\end{tabular}

\section{Copyright}

Copyright for this article is retained by the author(s), with first publication rights granted to the journal.

This is an open-access article distributed under the terms and conditions of the Creative Commons Attribution license (http://creativecommons.org/licenses/by/4.0/). 